\title{
The Evaluation of External Dose Rate Measurements of Patients During and After F-18 FDG PET/CT Imaging and Appropriate Discharge Time from PET/CT Department
}

\author{
F-18 FDG PET/BT Görüntüleme Yönteminin Tetkik Sürecinde ve Sonrasında Çevresel \\ Radyasyon Güvenliğinin Değerlendirilmesi
}

(D) Burçak Yılmaz Güneş, (D) Özlem Erez, (D) Cihan Gündoğan, (D) Nurhan Ergül

İstanbul Training and Research Hospital, Clinic of Nuclear Medicine, İstanbul, Turkey

\begin{abstract}
Introduction: F-18 radioisotope has higher photon energy when compared with other radioisotopes that are preferred in conventional imaging procedures in nuclear medicine. The aim of this study was to measure external radiation dose rate from patients injected with F-18 fluorodeoxyglucose (FDG) and to determine appropriate discharge time after F-18 FDG positron emission tomography/computed tomography (PET/CT) procedure.

Methods: Our study included $29(\mathrm{M} / \mathrm{F}=9 / 20)$ patients who were referred to nuclear medicine department for F-18 FDG PET/CT imaging. Dose rates were measured at a distance of $0,0.5,1$, 1.5 and $2 \mathrm{~m}$ from patients via Geiger-Müller probe at 3 different time points: 1) Just after the intravenous injection of F-18 FDG, 2) before PET/CT imaging and 3) just before discharge of patients from PET/CT department. Statistical analysis was performed to evaluate the differences between measurements.
\end{abstract}

Results: Patients were injected $291 \pm 62$ megabecquerel (MBq) (range: $226-440 \mathrm{MBq}$ ) F-18 FDG via IV route. The patients stayed in nuclear medicine department for $70.3 \pm 13.8$ min (range: $53 \mathrm{~min}-100 \mathrm{~min}$ ) after injection of F-18 FDG. Radiation dose velocity measurements taken at a distance of 1 meter were $39.7 \pm 11.9 \mu \mathrm{Sv} / \mathrm{h}$ just after the injection, $21.1 \pm 4.5 \mu \mathrm{Sv} / \mathrm{h}$ before $\mathrm{PET} / \mathrm{CT}$ examination and $14.3 \pm 2.9 \mu \mathrm{Sv} / \mathrm{h}$ just before discharge.

Conclusion: Although F-18 has high photon energy, its halflife is relatively short and this makes F-18 FDG an ideal radiopharmaceutical for PET/CT imaging. When the PET/CT scan is terminated, the dose rate measurements of the patients at a distance of $1 \mathrm{~m}$ are appropriate for discharge according to Turkish Atomic Energy Authority regulations. Therefore, patients can be safely discharged by explaining the necessary radiation safety measures after completing F-18 FDG PET/CT imaging.

Keywords: F-18 FDG, PET/CT, radiation safety, dose rate
öZ

Amaç: Nükleer tıpta pozitron emisyon tomografi/bilgisayarlı tomografi (PET/BT) görüntüleme yönteminde kullanılan F-18 radyoizotopu konvansiyonel nükleer tıpta tanı amacıyla kullanılan diğer radyoizotoplara göre daha yüksek foton enerjisine sahiptir. Çalıșmamızda rutin uygulamada yaygın olarak kullanılan F-18 fluorodeoksiglukoz (FDG), PET/BT cekimi için kullanılan F-18 FDG radyoizotopunun enjeksiyonundan sonra hastadan çevreye salınan radyasyonun doz hızının ölçülmesi ve çevresel radyasyon maruziyetinin değerlendirilmesi amaçlanmıştır.

Yöntemler: Çalışmamıza, Nükleer Tıp PET/BT ünitesine başvuran toplam $29(E / K=9 / 20)$ hasta dahil edilmiștir. Hastalara intravenöz (IV) olarak F-18 FDG enjekte edildikten hemen sonra, çekim öncesi ve taburcu edilmeden önce $0 \mathrm{~m}, 0,5 \mathrm{~m}, 1 \mathrm{~m}, 1,5 \mathrm{~m}$ ve $2 \mathrm{~m}$ mesafeden toraks düzeyinden Geiger-Müller sayacı kullanılarak doz hızı ölçümleri yapılmıștır. Her bir ölçümün ortalama ve standart sapma değerleri hesaplanmıș, ayrıca ölçümler arasında istatistiksel olarak anlamlı farklılık olup olmadığı değerlendirilmiștir.

Bulgular: Hastalara IV yol ile $291 \pm 62$ megabecquerel (MBq) (Aralık: 226-440 MBq) radyoaktif madde enjekte edilmis ve nükleer tıp kliniğinde enjeksiyon sonrası 70,3 $\pm 13,8 \mathrm{dk}$ (Aralık: 53 $\mathrm{dk}-100 \mathrm{dk}$ ) beklemiștir. Bir m mesafeden alınan radyasyon doz

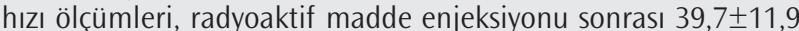
$\mu \mathrm{Sv} / \mathrm{sa}$, çekim esnasında $21,1 \pm 4,5 \mu \mathrm{Sv} / \mathrm{sa}$, taburcu anında $14,3 \pm 2,9 \mu \mathrm{Sv} / \mathrm{sa}$ olarak hesaplanmıștır.

Sonuç: F-18'in foton enerjisi 511 kilo elektron volt olmasına karșın nispeten kısa yarı ömürlü olmasından dolayı F-18 FDG tanı amacı ile kullanılabilen ideal bir radyofarmasötiktir. PET/ BT çekimi sonlandığında hastaların $1 \mathrm{~m}$ mesafedeki doz hızı ölcümlerinin, Türkive Atom Enerjisi Kurumu mevzuatları da göz önünde bulundurulduğunda, çevresel radyasyon güvenliği açısından bir tehlike arz etmediği gösterilmiștir. Bu nedenle hastalar F-18 FDG PET/BT görüntülemesi tamamlandıktan sonra gerekli radyasyon güvenlik önlemleri anlatılarak güvenli bir şekilde taburcu edilebilmektedir.

Anahtar Kelimeler: F-18 FDG, PET/BT, radyasyon güvenliği, doz hiz
Address for Correspondence/Yazıșma Adresi: Burçak Yılmaz Güneș MD, İstanbul Training and Research Hospital, Clinic of Nuclear Medicine, İstanbul, Turkey

Phone: +902124596000 E-mail: drburcak@gmail.com

Cite this article as/Atıf: Yılmaz Güneș B, Erez Ö, Gündoğan C, Ergül N. The Evaluation of External Dose Rate Measurements of Patients During and After F-18 FDG PET/CT Imaging and Appropriate Discharge Time from PET/CT Department. İstanbul Med J 2019; 20(3):188-92.

(C) Copyright 2019 by the Istanbul Training and Research Hospital/istanbul Medical Journal published by Galenos Publishing House.

(C) Telif Hakkı 2019 İstanbul Ĕgitim ve Araștırma Hastanesi/Istanbul Tıp Dergisi, Galenos Yayınevi tarafından basılmıștır.
Received/Geliș Tarihi: 20.10.2018 Accepted/Kabul Tarihi: 20.11.2018 


\section{Introduction}

18-Fluorodeoxyglucose (FDG) positron emission tomography/computed tomography (PET/ CT) is a non-invasive imaging method that has been widely used in nuclear medicine centers for many years with indications such as staging of various cancers, treatment response evaluation, restaging, radiotherapy planning, investigating the cause of unknown fever, differential diagnosis of dementia, investigation of epileptic focus, and infection imaging (1-4).

F-18 is a cyclotron product radioisotope. It emits positron and has a short physical half-life [(109.7 minute (min.)] (5). Although it has a short half-life, it has a significantly higher photon energy compared to the most commonly used technetium-99m in conventional nuclear medicine (140 keV and $511 \mathrm{keV}$, respectively). The most commonly used F-18 labeled metabolic product in daily life is FDG. FDG is a glucose analogue, and is taken into the cell through glucose transporters and is added to the glycolytic pathway. FDG accumulation in the tissues is observed proportional to the glucose utilization of the cells. Since intravenously administered F-18 FDG is excreted through the urinary tract, patients' micturition before PET/CT scan in order to reduce bladder activity is of great importance (5).

The minimum F-18 FDG activity required for PET/CT scan depends on the patient's age, body mass index, PET/CT device used and the scanning protocol (5). In this process, it is necessary to keep in mind the principles of the lowest possible dose (As low as reasonably achievable) for both patients and health workers (6-8).

The effective dose exposure of patients and those around them during diagnostic tests in nuclear medicine has been reported in national and international studies (9). In our country, according to the Turkish Atomic Energy Authority (TAEK) Law (No 2690), TAEK department of radiation health and safety implements the tasks, given by this law, concerning the services related to licensing, determination of the regulations and principles, and safe use of ionizing radiation and radioactive substances (10). The exemption limits of various radioisotopes used by TAEK in nuclear medicine are listed in annex-1 of the radiation safety regulation and it is reported as $106 \mathrm{~Bq}$ for F-18 (11). However, in the radiation safety regulation-annex-4, maximum reference levels per test for radionuclides and adult patients do not include any reference value for F-18-bound radioisotopes in the list (12). In this case, it is obvious that the evaluation of the external dose rate during discharge is important in order to ensure the radiation safety of the employees, patients and caregivers.

The aim of this study was to measure external radiation dose rate from patients injected with F-18 FDG and to determine appropriate discharge time after PET/CT scan.

\section{Methods}

\section{Patient Population}

This prospective study was approved by the local ethics committee (İstanbul Şş̧li Hamidiye Etfal Training and Research Hospital, Clinical Research Ethics Committee (decision no: 2017-1506). Patients over 18 years of age who were randomly selected among the patients who applied to the nuclear medicine clinic for whole-body F-18 FDG PET/ CT scan with various indications for 5 days consecutively were included in the study. Patients under 18 years of age, patients with known renal insufficiency, patients with problems with urinary system (patients with urinary catheter, patients with urinary output problems, etc.) and patients with Eastern Cooperative Oncology Group performance score $\geq 3$ were not included in the study. A total of 29 patients ( 20 female, 9 male; 59.4 years \pm 12.4 years) who met the inclusion criteria and accepted to participate were included in the study and informed consent forms were obtained. Patients were trained for radiation safety prior to scanning in accordance with the TAEK radiation safety regulations and annex-6, and things to do during and after scanning were described verbally in detail and given as texts (13).

\section{Study Design, Data Collection and External Dose Rate Measurement}

For F-18 FDG PET/CT scan, blood glucose levels of patients were measured following 4-6 hours of fasting. Patients with fasting glucose levels $<200$ $\mathrm{mg} / \mathrm{dL}$ were injected intravenously with $291 \pm 62 \mathrm{MBq}$ (range: $226-440$ $\mathrm{MBq}$ ) F-18 FDG according to the European Nuclear Medicine Association FDG PET/CT guideline version 2 recommendations (5). After the injection, the patients consumed an average of 1 liters of water.

Dose rate measurements were performed by Geiger-Müller (GM) probe (Eberline ESP-2, NM, USA) calibrated by Secondary Standard Dosimeter Laboratory of İstanbul Çekmece Nuclear Research and Training Center. The accuracy of the GM probe has been reported to be within $\pm 3 \%$ range (14). Using this detector, external dose rate measurements were made at three different times from $0,0.5,1,1.5$ and $2 \mathrm{~m}$ distance from the central part of the thorax for a total of 15 times for each patient. The first measurements were taken immediately after the F-18 FDG injection, the second measurements were taken just before the scan after micturition and the third measurements were taken after PET/CT scan just before leaving the nuclear medicine clinic after micturition.

Patients were kept in private rooms with bulletproof insulations in the department until discharge. Patients' height, weight, injection and scan hours, measurement hours and results were recorded.

\section{Statistical Analysis}

The mean and standard deviation values of age, body weight, height, length of stay in the nuclear medicine clinic after injection, and external dose rates were calculated. The statistical significance of the differences between dose rate measurements was evaluated by Student's t-test. $\mathrm{P}<0.05$ was considered statistically significant.

\section{Results}

The age of the patients included in the study was $59.4 \pm 12.4$ years (range: 41-81 years). Mean body weight was $72.8 \pm 18.5 \mathrm{~kg}$ (range: $50-120 \mathrm{~kg}$ ) and height was $161.83 \pm 8.34 \mathrm{~cm}$ (range: $150-180 \mathrm{~cm}$ ). The mean length of stay in the nuclear medicine department from the moment of F-18 FDG injection until discharge was 70.3 $\pm 13.8 \mathrm{~min}$ (range: 53-100 min).

Mean dose rates calculated from measurements taken with GM counter at $0,0.5,1,1.5$ and $2 \mathrm{~m}$ distance from the thorax level immediately after the injection, immediately before scanning after micturition and before 
Table 1. Dose rate measurements

\begin{tabular}{|l|l|l|l|}
\hline $\begin{array}{l}\text { Dose rate } \\
\text { measuring } \\
\text { distance }(\text { meters })\end{array}$ & $\begin{array}{l}\text { Immediately } \\
\text { after the } \\
\text { injection }(\boldsymbol{\mu S v} / \mathrm{h})\end{array}$ & $\begin{array}{l}\text { Immediately } \\
\text { before scanning } \\
(\boldsymbol{\mu} \mathrm{S} / \mathrm{h})\end{array}$ & $\begin{array}{l}\text { Before } \\
\text { discharge } \\
(\boldsymbol{\mu S v} / \mathrm{h})\end{array}$ \\
\hline 0 & $718.31 \pm 186.33$ & $222.03 \pm 59.47$ & $148.61 \pm 43.73$ \\
\hline 0.5 & $117.97 \pm 44.02$ & $49.31 \pm 14.49$ & $33.68 \pm 9.14$ \\
\hline 1 & $39.66 \pm 11.91$ & $21.07 \pm 4.49$ & $14.28 \pm 2.94$ \\
\hline 1.5 & $18.45 \pm 4.95$ & $11.10 \pm 2.23$ & $8.04 \pm 1.79$ \\
\hline 2 & $12.10 \pm 2.95$ & $6.62 \pm 1.89$ & $4.25 \pm 1.65$ \\
\hline
\end{tabular}
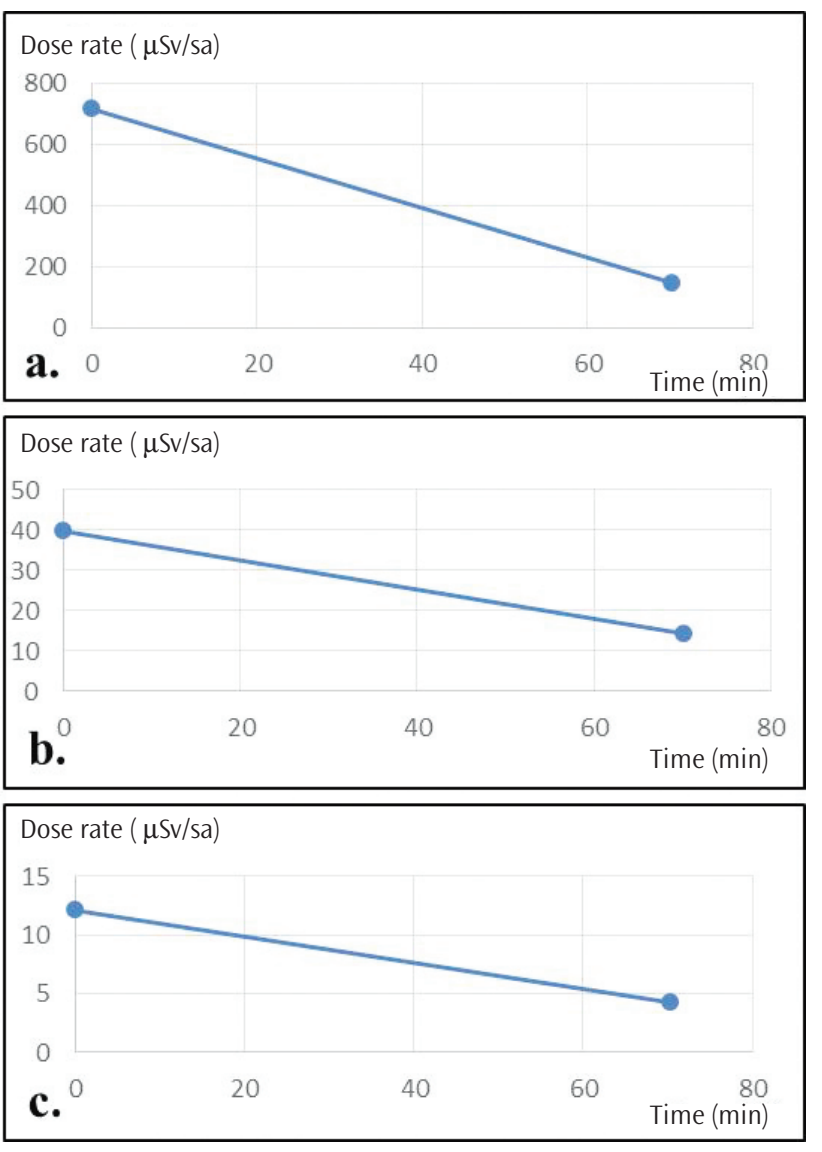

Figure 1. Dose rates versus time from $0 \mathrm{a}), 1 \mathrm{~b}$ ) and $2 \mathrm{~m} \mathrm{c}$ )

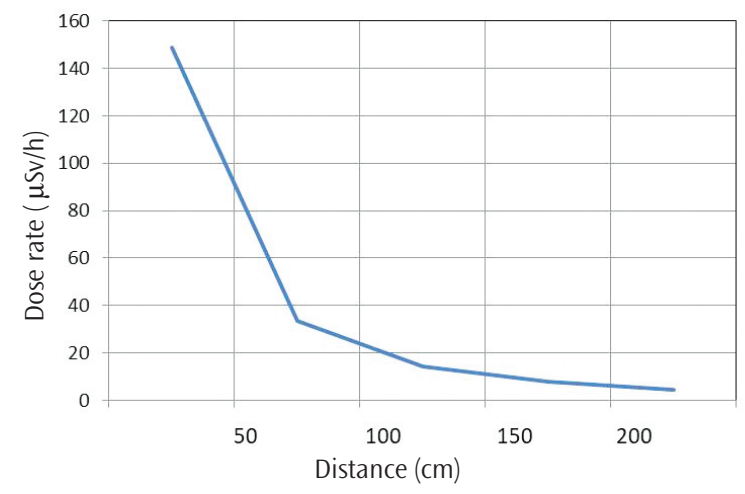

Figure 2 . The relationship between mean dose rate $(\mu \mathrm{Sv} / \mathrm{h})$ and distance (cm) during discharge discharge after micturition were given in Table 1. Also, Figure 1 shows the dose rate measurements from $0 \mathrm{~m}, 1 \mathrm{~m}$ and $2 \mathrm{~m}$ distances versus time, and Figure 2 shows the relation between distance and mean dose rates during discharge.

A significant difference was found between the dose rates at 0,1 and 2 $m$ distance $(p<0.001)$. A significant difference was found between the dose rates at different times in the measurements taken at the same distance $(p<0.001)$. Although there is no data by TAEK regarding external dose rates of F-18-bound radiopharmaceuticals during discharge, the discharge limit for I-131 was determined as safety limit dose rate $<30$ $\mu \mathrm{Sv} / \mathrm{h}$ in annex- 5 of the Radiation Safety Regulation (15). All patients included in our study were able to be discharged with safe dose rate with an external dose rate of $14.3 \pm 2.9 \mu \mathrm{Sv} / \mathrm{h}$ (range: $8-21 \mu \mathrm{Sv} / \mathrm{h}$ ) at a distance of 1 meter at the end of scanning.

\section{Discussion}

In our country, patients receiving radionuclide treatment according to TAEK regulations are kept in private single rooms with isolation until the dose rate level is reduced to $<30 \mu \mathrm{Sv} / \mathrm{h}$. The external dose rate limits during discharge are $<50 \mu \mathrm{Sv} / \mathrm{h}$ in the United States and $<20 \mu \mathrm{Sv} / \mathrm{h}$ in European Union countries $(16,17)$. Although defined values have been determined for radionuclide treatments, it has been shown that discharge rate limits are rapidly achieved in our country and European Union countries in nuclear medicine during the time for PET-BT scanning regarding the short half-life of the F-18 isotope, relatively low level of radioactivity compared to treatment and biological elimination of F-18 isotope used for diagnosis in our study, but with a high photon energy.

International (International Commission on Radiological Protection) and national (TAEK) radiation protection institutions have reported an annual acceptable radiation (internal and/or external) exposure dose for individuals in the community as $1 \mathrm{mSv}(18,19)$. In addition, in the manual published by TAEK, it has been described that dose limits above this level are acceptable in adults who are knowingly and intentionally near the patients who had radioactive substance for diagnostic or therapeutic purposes. The effective dose in caregivers or those who come for a patient visit has been reported not to exceed $5 \mathrm{mSv}$ during diagnosis and treatment. In addition, it has also been explained that patient-induced dose exposure should not exceed $1 \mathrm{mSv}$ for pregnant women and children (9).

In our study, although the external dose limits of patients during discharge are well below the criteria determined in accordance with the legal regulations, it is necessary to prevent unnecessary radiation exposure of the people and the society around the patient who underwent radioactive material and became a source of radiation for a certain period of time (9). This is also important for the hospital staff working in the services of the patients as well as staff working in the nuclear medicine clinics. It has been reported that if the patient transfers are performed with the same personnel, the personnel will be exposed to $0.1 \mathrm{mSv} / \mathrm{month}$ radiation because the distance between the staff in charge of transporting the inpatients to the relevant services and the patient is very low (9). In another study, it was suggested that the hospital staff accompanying the patient or the patient's relative should 
accompany the patients by at least $0.5 \mathrm{~m}$ distance if possible, within 2 hours of F-18 FDG injection (20). In addition, the highest exposure dose of the nurse working in the intensive care unit was reported to be due to myocardial perfusion scintigraphy studies or positron emission imaging studies (21). The exposure dose of the personnel working outside the nuclear medicine clinic is related to the time taken for the patient to reach the relevant service after radionuclide injection. Although radionuclide agents and application doses vary with the doses administered, the time spent in delivering the patients from the nuclear medicine department to the service will decrease the external dose rates and decrease the exposure of the personnel (21-23). In a study by Cronin et al. (23), it was shown that there was no need for severe limitations for inpatients who had undergone F-18 FDG PET imaging and who remained in the nuclear medicine unit for 2 hours after injection. Care should be taken not to establish close contact only with children and pregnant women for at least 6 hours after injection (20).

In studies conducted, it was shown that the radiation technicians working in the nuclear medicine clinic were below the $20 \mathrm{mSv} / \mathrm{year}$ dose limits (24). It was claimed that approximately $60 \%$ of this exposures was due to contact with radioactive material and about $40 \%$ was due to close contact with the patients (24). In this case, the radiation safety personnel as we have shown in our study can reduce the radiation dose to a significant extent by paying attention to distance between the patient injected with a radioactive substance during his/her stay in the clinic and by keeping the contact with radioactive material as short as possible $(20,25,26)$.

The minimum F-18 FDG activity required for PET-CT scan depends on the device used and the patient's body weight $(27,28)$. On the other hand, the maximum dose that can be applied has been reported in some countries (5). However, maximum normal activity level for F-18 radioisotope are not specified in annex-4 of TAEK Radiation Safety Regulation, in which the maximum normal activity levels of radioisotopes used for diagnostic methods in nuclear medicine in our country. In our daily practice, as stated in our study, we inject F-18 FDG and discharge our patients according to European Association of Nuclear Medicine guideline and International Commission on Radiological Protection recommendations $(5,18,29-31)$.

In addition, it is very important that patients are hydrated and micturition is achieved before and after F-18 FDG PET/CT. Bladder is the organ that receives the most radiation dose in the F-18 FDG PET procedure. Prompting patients to drink water during F-18 FDG injection until after scanning reduces bladder radiation dose and thus external dose rate levels (26).

\section{Conclusion}

According to the results of this study, despite having a physical half life of 109.8 min., it was determined that more than half of the F-18 radioactive material was discarded after about 60 minutes through biological elimination, hydration and micturition. Since external dose rate at a distance of $1 \mathrm{~m}$ from the patient does not pose a risk for environmental radiation safety after F-18 FDG PET/CT procedure, it is concluded that patients can be safely discharged by explaining the necessary radiation safety measures immediately after the examination.
Ethics Committee Approval: İstanbul Şişli Hamidiye Etfal Training and Research Hospital, Clinical Research Ethics Committee (decision no: 2017-1506).

Informed Consent: Informed consent forms were obtained.

Peer-review: External and internal peer-reviewed.

Author Contributions: Concept - B.Y.G.; Design - B.Y.G.; Supervision - B.Y.G.; Resources - Ö.E.; Materials - Ö.E.; Data Collection and/or Processing - B.Y.G., Ö.E.; Analysis and/or Interpretation - B.Y.G., Ö.E., C.G., N.E.; Literature Search - C.G.; Writing Manuscript - B.Y.G.; Critical Review - Ö.E., C.G., N.E.

Conflict of Interest: No conflict of interest was declared by the authors.

Financial Disclosure: The authors declared that this study received no financial support.

\section{References}

1. Gunes BY, Onsel C, Sonmezoglu K, Ozaras R, Halac M, Tabak F, et al. Diagnostic value of F-18 FDG PET/CT in patients with spondylodiscitis: Is dual time point imaging time worthy? Diagn Microbiol Infect Dis 2016; 85: 381-5.

2. Ergul N, Kadioglu H, Yildiz S, Yucel SB, Gucin Z, Erdogan EB, et al. Assessment of multifocality and axillary nodal involvement in early-stage breast cancer patients using 18F-FDG PET/CT compared to contrast-enhanced and diffusionweighted magnetic resonance imaging and sentinel node biopsy. Acta Radiol 2015; 56: 917-23.

3. Ergül N, Cermik TF. FDG-PET or PET/CT in Fever of unknown origin: The diagnostic role of underlying primary disease. Int J Mol Imaging 2011; 2011 318051.

4. Akaike G, Itani M, Shah H, Ahuja J, Yilmaz Gunes B, Assaker R, et al. PET/CT in the diagnosis and workup of sarcoidosis: Focus on atypical manifestations. Radiographics 2018; 38: 1536-49.

5. Boellaard R, Delgado-Bolton R, Oyen WJ, Giammarile F, Tatsch K, Eschner W, et al. FDG PET/CT: EANM procedure guidelines for tumour imaging: version 2.0. Eur J Nucl Med Mol Imaging 2015; 42: 328-54.

6. Atci IB, Yilmaz H, Antar V, Ozdemir NG, Baran O, Sadillioglu S, et al. What do we know about ALARA? Is our knowledge sufficient about radiation safety? J Neurosurg Sci 2017; 61: 597-602.

7. Siegel JA, Sacks B, Pennington CW, Welsh JS. Dose optimization to minimize radiation risk for children undergoing $\mathrm{CT}$ and nuclear medicine imaging is misguided and detrimental. J Nucl Med 2017; 58: 865-8.

8. Chen MK, Menard DH $3^{\text {rd }}$, Cheng DW. Determining the minimal required radioactivity of 18F-FDG for reliable semiquantification in PET/CT imaging: A Phantom Study. J Nucl Med Technol 2016; 44: 26-30.

9. Aras F, Kıraç S, Ayan A, Değer M, Demir M, Dönmez S, et al. Radiation safety process for the patient and people around during diagnostic radionuclide studies. Nucl Med Semin 2016; 3: 172-175.

10. Türkiye Atom Enerjisi Kurumu Kanunu. Kanun No: 2690. R.G: 13.7.1982/17753.

11. TAEK (Türkiye Atom Enerjisi Kurumu), Radyasyon Güvenliği Yönetmeliği Ek-1

12. TAEK (Türkiye Atom Enerjisi Kurumu), Radyasyon Güvenliği Yönetmeliği Ek-4

13. TAEK (Türkiye Atom Enerjisi Kurumu), Radyasyon Güvenliği Yönetmeliği Ek-6

14. Yeyin N, Abuqbeitah M, Çavdar I, Sönmezoğlu K, Demir M. The evaluation of dose rate measurements and discharge time after radionuclide therapy. J Ist Faculty Med 2017; 80: 1.

15. TAEK (Türkiye Atom Enerjisi Kurumu), Radyasyon Güvenliği Yönetmeliği Ek-5

16. European Commission Radiation Protection 97: Radiation Protection Following lodine-131 Therapy (Exposure due to out-patients or discharged 
inpatients). Luxembourg, Belgium: Office for Official Publications of the European Communities; 1998.

17. Yeyin N, Demir M. Hasta ve atıklarından çevreye salınan radyasyon miktarının belirlenmesi ve doz hızı ölçümleri. 1.Ulusal Sağlık Kuruluşları Çevre Yönetim Sempozyumu Yayınları, İstanbul, 29-30 Kasım 2012.

18. ICRP. Radiation dose to patients from radiopharmaceuticals. Addendum 3 to ICRP Publication 53. ICRP Publication 106. Approved by the Commission in October 2007. Ann ICRP 2008; 38: 1-197.

19. Radyonüklit tedavisi gören hastaların taburcu edilmesine ilișkin kılavuz. RSGD-KLV-009. TAEK, Ankara, 14 Kasım 2016.

20. Demir M, Demir B, Sayman H, Sager S, Sabbir Ahmed A, Uslu I. Radiation protection for accompanying person and radiation workers in PET/CT. Radiat Prot Dosimetry 2011; 147: 528-32.

21. Bartlett ML. Estimated dose from diagnostic nuclear medicine patients to people outside the Nuclear Medicine department. Radiat Prot Dosimetry 2013; 157: 44-52

22. Mountford PJ, O'Doherty MJ. Exposure of critical groups to nuclear medicine patients. Appl Radiat Isot 1999; 50: 89-111.

23. Cronin B, Marsden PK, O'Doherty MJ. Are restrictions to behaviour of patients required following fluorine-18 fluorodeoxyglucose positron emission tomographic studies? Eur J Nucl Med 1999; 26: 121-8.
24. Seierstad T, Stranden E, Bjering K, Evensen M, Holt A, Michalsen HM, Wetteland 0 . Doses to nuclear technicians in a dedicated PET/CT centre utilising $18 \mathrm{~F}$ fluorodeoxyglucose (FDG). Radiat Prot Dosimetry 2007; 123: 246-9.

25. Demir M, Demir B, Yasar D, Sayman HB, Halaç M, Ahmed AS, et al. Radiation doses to technologists working with 18F-FDG in a PET center with high patient capacity. Nukleonika 2010; 55: 107-12.

26. Alenezi A, Soliman K. Trends in radiation protection of positron emission tomography/computed tomography imaging. Ann ICRP 2015; 44: 259-75.

27. de Groot EH, Post N, Boellaard R, Wagenaar NR, Willemsen AT, van Dalen JA. Optimized dose regimen for whole-body FDG-PET imaging. EJNMMI Res 2013; 3: 63.

28. Masuda Y, Kondo C, Matsuo Y, Uetani M, Kusakabe K. Comparison of imaging protocols for 18F-FDG PET/CT in overweight patients: optimizing scan duration versus administered dose. J Nucl Med 2009; 50: 844-8.

29. Radiation protection and safety of radiation sources: international basic safety standards. IAEA General Safety Requirements. GSR 2014; 3: 10-11.

30. Stabin MG. Radiopharmaceuticals for Nuclear Cardiology: Radiation Dosimetry, Uncertainties, and Risk. J Nucl Med 2008; 49: 1555-63.

31. Radiation Dose to Patients from Radiopharmaceuticals. ICRP 2007. 